\title{
Article \\ Huddle Up! Exploring Domestic Coalition Formation Dynamics in the Differentiated Politicization of TTIP
}

\author{
Niels Gheyle \\ Department of Political Science, Ghent University, 9000 Ghent, Belgium; E-Mail: niels.gheyle@ugent.be
}

Submitted: 30 October 2019 | Accepted: 6 February 2020 | Published: 31 March 2020

\begin{abstract}
The politicization of the Transatlantic Trade and Investment Partnership (TTIP) has manifested itself to different extents across EU Member States. In some countries, conflicting interpretations about the deal were highly visible in public and political debates, while in others there was hardly any awareness. To further understand this phenomenon, trade scholars have to date not yet deepened nor leveraged the insights of the 'differentiated politicization' and social movement literature, which both point to coalition formation as an important trigger of politicization processes. This article contributes to our understanding of variation in politicization across EU Member States, by exploring coalition formation dynamics in differentiated politicization processes, in order to identify the factors facilitating successful domestic coalition formation. Through an exploratory case study design, I focus on three countries that exemplify high, middle, and low politicization cases: Germany, Belgium, and Ireland. By relying on the testimonies of campaigners active during the TTIP episode, I identify three elements that facilitated the formation of a diverse domestic coalition, which subsequently played an important role in pushing for a broad-based debate about the implications of TTIP: (i) an expert 'mesomobilization' link with a transnational advocacy network, (ii) the prior availability of domestic alliances, and (iii) an inclusive framing approach in order to establish a diverse coalition. The findings also underline the importance of timing in the unfolding of (successful) politicization processes.
\end{abstract}

\section{Keywords}

alliances; coalition formation; contestation; European Union; networks; politicization; trade; Transatlantic Trade and Investment Partnership

\section{Issue}

This article is part of the issue "Politicization of EU Trade Policy across Time and Space" edited by Dirk De Bièvre (University of Antwerp, Belgium), Oriol Costa (Universitat Autònoma de Barcelona, Spain/IBEI, Spain), Leif Johan Eliasson (East Stroudsburg University, USA) and Patricia Garcia-Duran (University of Barcelona, Spain).

(C) 2020 by the author; licensee Cogitatio (Lisbon, Portugal). This article is licensed under a Creative Commons Attribution 4.0 International License (CC BY).

\section{Introduction}

The Transatlantic Trade and Investment Partnership (TTIP) has gone down in memory as the most politicized EU trade negotiation to date. Between 2013 and 2016, political parties, NGOs, business groups, farmers' associations and citizen movements across Europe were involved in an enduring public and political debate about the opportunities and risks of such a transatlantic free trade agreement. That collective attention turned to this particular deal was in part due to the farreaching market-(de)regulating nature of the deal, spark- ing normative, value-based concerns, instead of purely economic motivations (De Ville \& Siles-Brügge, 2017; Laursen \& Roederer-Rynning, 2017). This combination of the high ambitions of the negotiators, and the equally strong politicization that followed in its wake, make TTIP an extreme case that can illuminate new insights for scholars studying the ever-deepening nature of EU trade agreements, or the societal reaction it provokes.

From the latter point of view, one of the most striking observations about the TTIP episode is that notwithstanding the overall unprecedented level of politicization surrounding TTIP, it has been politicized to very differ- 
ent degrees across EU Member States (Gheyle, 2019; Meunier \& Czesana, 2019). Conflicting interpretations about TTIP were highly visible in the public and political spheres of Germany and Austria, were present to some degree in France, the UK or Belgium, while there was hardly any visible conflict in, for example, Ireland, Greece or the Central and Eastern European countries.

EU trade policy scholars have to date, however, predominantly focused on the question why TTIP experienced such a strong societal reaction, while other (even parallel) trade agreements did not. Several factors are identified, such as the far-reaching content of the deal (De Bièvre \& Poletti, 2017; De Ville \& Siles-Brügge, 2017), the power symmetry with the negotiating partner (Young, 2016), the broad and sustained activism of civil society organizations (De Ville \& Siles-Brügge, 2015; Eliasson \& Garcia-Duran, 2018), or the use of particular framing, 'myths' and narratives (Buonanno, 2017; Duina, 2019). One exception is the study by Jedinger and Schoen (2018), which focuses on differences in public opinion (in particular anti-Americanism), which they nevertheless find to be moderated by issue awareness and political framing, and therefore not in itself an explanation for the differences observed.

This article aims to contribute to an understanding of variation in politicization across EU Member States. The theoretical starting point of the analysis is the literature on the 'politicization of European integration,' which takes issue with the increasing and visible controversy over the EU and its activities (de Wilde, 2011; Schmidt, 2019). This literature has made considerable steps towards explaining differentiated politicization across time and settings (de Wilde, Leupold, \& Schmidtke, 2016). One of its findings is that, given the actor-driven nature of politicization processes, resource mobilization is quintessential to expanding the scope of conflict (see Zürn, 2018). By connecting this concept to social movement and interest group literature, coalition formation comes to the fore as a crucial element: By building alliances, a multitude of useful campaigning resources are pooled/mobilized (expertise, experience, funding, staff, reputation), essential to kick-start a durable mobilization and politicization process (Crespy, 2016; Junk, 2019).

However, this insight has not yet been deepened, nor leveraged in the study of the differentiated politicization of TTIP. With coalition formation as a key element in pushing politicization processes comes the expectation that different dynamics of coalition formation should be related to different degrees of politicization across contexts. The main goal of this article is therefore to explore coalition formation dynamics in three EU Member States that experienced divergent levels of politicization, in order to identify which factors account for successful domestic coalition formation efforts and subsequent politicization. To do that, I not only build on the analysis of primary documents (joint position papers and website information), but especially rely on the testimonies of activists and campaigners centrally in- volved in the mobilization against TTIP, based on 28 semistructured interviews.

As the aim is to generate new insights into the role of coalition formation in domestic politicization dynamics of EU trade agreements, the case study design is exploratory, and follows an abductive logic (Friedrichs \& Kratochwil, 2009). This means I start, in the next section, by reviewing the concept of coalition formation within the broader politicization and social movement literature, in order to generate suggestions about the factors facilitating successful coalition formation in politicization processes (Section 2). Section 3 explains the case selection and interview strategy of this exploratory case study design. This is then followed by an empirical analysis of the coalition formation dynamics in Germany, Ireland and Belgium (Section 4). The discussion and conclusions summarize the main findings and discuss how these can serve as the basis for further research (Section 5).

\section{Politicization and Domestic Coalition Formation}

\subsection{The Importance of Coalition Formation in Politicization Processes}

The politicization of the EU has been seminally defined as "an increase in polarization of opinions, interests or values and the extent to which they are publicly advanced towards the process of policy formulation within the EU" (de Wilde, 2011, p. 566). While scholars have rightly operationalized this as a multi-dimensional phenomenon (Baglioni \& Hurrelmann, 2016; Zürn, 2016), its communicative or discursive manifestation is an oftenrecurring feature. In this view, politicization can be seen as characteristic of a public and political debate that combines 'visibility' with 'conflicting interpretations,' usually put forward by a variety of actors beyond EU executives (de Wilde et al., 2016; Statham \& Trenz, 2013). In other words, EU politicization describes a process whereby traditional backroom negotiations between (executive) elites are accompanied by visible public and political debates in parliaments, mass media or on the streets.

Crucially though, the politicization of an issue is not an automatic process, but is driven by actors who attempt to politicize something, by discursively (re)inserting conflict or contingency surrounding a topic where before there was none or too little (Palonen et al., 2019). A politician, an NGO activist, or a citizen, can all try to politicize an EU free trade agreement by arguing, for example, that a deal is not about economic benefits, but about democracy and transparency. Yet whether this intervention will spark a broader public and political debate where 'markets' and 'democracy' become the main points of reference, depends on a variety of mediating factors.

Recent contributions have therefore focused on the 'black box' of politicization dynamics: the process of unfolding politicization. As politicization predominantly takes place at domestic levels, this focus is especially rel- 
evant to account for differences across time and settings. Contributions have converged around two broad categories that serve as mediating categories: 'political opportunity structures' and 'resource mobilization' (Crespy, 2016; de Wilde \& Zürn, 2012; Zürn, 2016). In short, politicization will unfold in contexts where resources are 'mobilized' (pooled, activated, put forward publicly) in a setting that is conducive for such mobilization to take place and spill over to a wider audience.

This focus on resource mobilization connects the politicization literature to social movement and interest group studies, and the 'resource mobilization theory' in particular. The key insight here is that the availability of resources (be it material, financial, reputational or cultural) enhances the probability that collective action will occur, but only if coordination and strategic effort first convert these into collective resources (McCarthy \& Zald, 1977). While different modes of 'access' to resources exist, the creation of 'organizational capacity' or movement structures, is identified as the most important (Edwards \& McCarthy, 2007). By forming coalitions, organizations and individuals pool financial resources, increase staff efficiency, exchange information, and decide on common strategies and frames-dynamics that contribute to sustained activism and subsequent politicization.

This finding is empirically corroborated in different literatures. For example, several authors using the politicization concept explicitly link this with coalition formation. Crespy (2016) argued that coalition formation is the first step of an unfolding politicization process, and empirically shows that the simultaneous activation of transnational, supranational and domestic channels of coalition formation has played a key role in politicizing EU legislation on welfare market liberalization. Zürn (2018) similarly finds that with respect to human rights provisions in international organizations' policies, it was those challengers who built coalitions with legislative, judicial or like-minded institutions (other organizations, states) that succeeded in politicizing the issue, forcing concessions of the organization.

Empirical studies on interest group lobbying equally find that the existence of coalitions and their collective framing efforts are decisive for lobbying success or influence (Baumgartner \& Mahoney, 2008; Junk \& Rasmussen, 2019). Moreover, in examples of contentious trade negotiations in the past as well, coalition formation has played a recurrent role in fueling politicization. The 'Battle of Seattle' during the WTO Ministerial Conference of 1999, for example, turned into a successful mobilization only after divergent groups were able to find common ground and form an event coalition (Levi \& Murphy, 2006). Successful cases of politicizing the General Agreement on Trade in Services were equally related to the work of dense coalitions of activists (Crespy, 2016). Finally, the politicization and derailing of the AntiCounterfeiting Agreement equally suggests advocacy by organized groups as essential (Crespy \& Parks, 2017).

\subsection{Determinants of Successful Coalition Formation}

Following Crespy's (2016) discursive institutionalist position, successful politicization efforts are shaped by the necessity to rally the relevant allies in a given institutional setting. In post-Lisbon EU trade policy, the European Parliament has de facto veto power over international agreements at the end of a negotiation process, while national parliaments need to ratify ('mixed agreement') deals if they touch upon domestic competences. Given this power-sharing across levels, successfully politicizing TTIP therefore implies activating transnational, supranational, and domestic channels of mobilization and coalition formation. Combining social movement, interest group and EU politicization literature, I put forward three factors that come forward as facilitating domestic coalition formation in this context, and pushing the politicization process.

First of all, social movement scholars put a particular emphasis on 'mediating structures' to explain successful activation of resources (Staggenborg, 2002). So-called 'mesomobilization actors' are identified as the groups (or individual actors) that coordinate and integrate micromobilization groups (Gerhards \& Rucht, 1992). They are actors who take up the coordination and organizational integration of different groups that are engaged with an issue. The effectiveness of such actors is usually correlated with their prior experience in mobilizing or coordinating tasks. In case of high domestic TTIP politicization, we therefore expect mesomobilization actors to have played an important coordinating role at the domestic level.

Secondly, the prior availability of networks may also play an important role. Pre-existing links and alliances often get picked up (again) when the need arises. If coalition formation still needs to occur after negotiations have already begun, there may be a missed opportunity to weigh in on the terms of the debate. Again, examples from the trade literature confirm this point. Walter (2001) argued that "it is difficult to understand NGO opposition to the Millennium Round agenda in Seattle in 1999 without addressing their opposition to and mobilization against the MAI [Multilateral Agreement on Investment]" (p. 52). Von Bülow (2010) equally found that anti-trade coalition building in Central and North America in the 1990s was more sustainable when actors could build on pre-existing social networks, repertoires, and resources. In Europe as well, a core group of organizations has been involved in several mobilization episodes (Crespy, 2014).

Thirdly, coalitions can probably politicize issues more effectively when they link a diverse set of organizations together, as this pools different types of expertise, reputations, political links and mobilization potential. To allow for such heterogeneous coalition building, issue framing plays a crucial role by altering the nature and scope of potential overlap (Levi \& Murphy, 2006). Moreover, Gerhards and Rucht (1992) found that it is often the task 
of the mesomobilization actors to provide the 'cultural glue' of coalitions by elaborating collective action frames binding groups together. This is especially important for advocacy coalitions that link unusual partners (such as trade unions and social movements), or organizations with different objectives (Benford \& Snow, 2000; Keck \& Sikkink, 1998).

\section{Research Design}

This study uses an exploratory (theory-building) case study design in order to identify the factors that facilitated successful coalition formation across divergent politicization paths (Rohlfing, 2012). The research approach taken is abductive, which implies that I started by using existing, related, literature as a guide for what we could expect to find, leaving room for rich empirical analysis to further inform these (Friedrichs \& Kratochwil, 2009). Case selection in exploratory and abductive research designs often follows a '(most-)typical' or 'mostinteresting' logic (Friedrichs \& Kratochwil, 2009; Rohlfing, 2012), which means I am interested in three cases that differ on the outcome (degree of politicization high, middle, low), while serving as interesting or exemplary cases for each of these categories.

Nonetheless, the measurement of politicization processes or degrees is notoriously complicated, not only because the concept tries to tie together different societal dynamics, such as public opinion awareness, media visibility, parliamentary debates, or protest events (de Wilde, 2011), but also because scholars differ in the way they conceptualize politics and politicization (see, e.g., Palonen et al., 2019). Any comparison based on a single measurement will therefore always be a contentious choice.

Building on a broader project focusing on TTIP politicization dynamics in different countries (Gheyle, 2019), I have therefore attempted to address this problem by following a step-wise strategy, combining different partial indicators in order to justify case selection. First, building on the assumption that differences in the intensity of the anti-TTIP campaign are the most likely explanation for the variation in opposition to TTIP (Young, 2017), I rely on public opinion data about variation in opposition against TTIP to make a first distinction. Table 1 of the Supplementary File gives an overview of (changes in the) support and opposition levels across all EU Member States.

Germany and Austria stand out as the countries with the highest shares of opposition against TTIP, which further deteriorate over time. This is in line with several scholarly and practitioners' assessments of Germany as the most politicized case (e.g., Chan \& Crawford, 2017). Given Germany's pivotal function in the EU, and its traditional support for EU trade deals, this is therefore a typical and interesting case of high politicization. On the other side of the spectrum, Ireland stands out as the only case with extremely high support levels, which even increase over time, suggesting very low levels of politicization. Moreover, its historical position and links with the US make this an equally interesting case to focus on. Lastly, as a 'middle-range' case, Belgium was chosen, primarily given the divergences between the two regions, Flanders and Wallonia, which both showed declining levels of support over time, yet started from a respectively high and medium level. These different experiences between two regions with far-reaching powers in international negotiations makes for an interesting comparison of coalition dynamics (Bollen, De Ville, \& Gheyle, 2020).

As a second step, I calculated 'politicization indices' for each of the three (four) cases. Through a quantitative media content analysis, I extracted so-called 'core sentences' from articles on the TTIP topic (Gheyle, 2019). These sentences include evaluations of TTIP uttered by an actor, with a certain frame attached to it. I aggregated these data into indicators of 'salience,' 'actor expansion' and 'polarization' (key indicators of politicization, see de Wilde et al., 2016), and combined these into one politicization index with the formula 'salience $\times$ (actor expansion + polarization).' Figure 1 plots these indices over time, which again shows that Germany was a standout politicization case from the very beginning of negotiations. Politicization in Wallonia (according to this partial indicator) only took off in early 2015 but then remained at a relatively high level, before peaking late 2016. The trajectories of Ireland and Flanders are quantitatively rather similar, with two peaks in early 2015 and late 2016.

But again this indicator was unable to capture everything, especially neglecting several political and parliamentary dynamics. Further qualitative evidence of the amount and content of parliamentary debates showed that Flanders could be classified as relatively more politicized than Ireland (where hardly any political party contestation was registered), while in Wallonia and Germany, there was a lot of debate on the topic, in line with the above observations (Bollen et al., 2020; Gheyle, 2019).

All in all, I am confident that the cases of Germany, Wallonia, Flanders, and Ireland, can be depicted as high, middle-high, middle-low, and low cases of politicization, respectively.

To gain information and a deeper understanding of what facilitated domestic coalition formation in these countries, I built on a diverse range of written sources (such as position papers or website information), but especially relied on testimonies of activists and campaigners heavily involved in the TTIP campaign. They are wellplaced not only to describe (internal) coalition-building dynamics, but also to evaluate the significance hereof in the broader scheme of things. In total, I conducted 28 semi-structured interviews with civil society representatives in the three countries, in the period 2015-2016. For the current purposes (and reasons of scope), only a selection of key interviews is referenced. References to the numerical interviews below can be found in the online supplementary file. 


\section{Politicization indices over time}

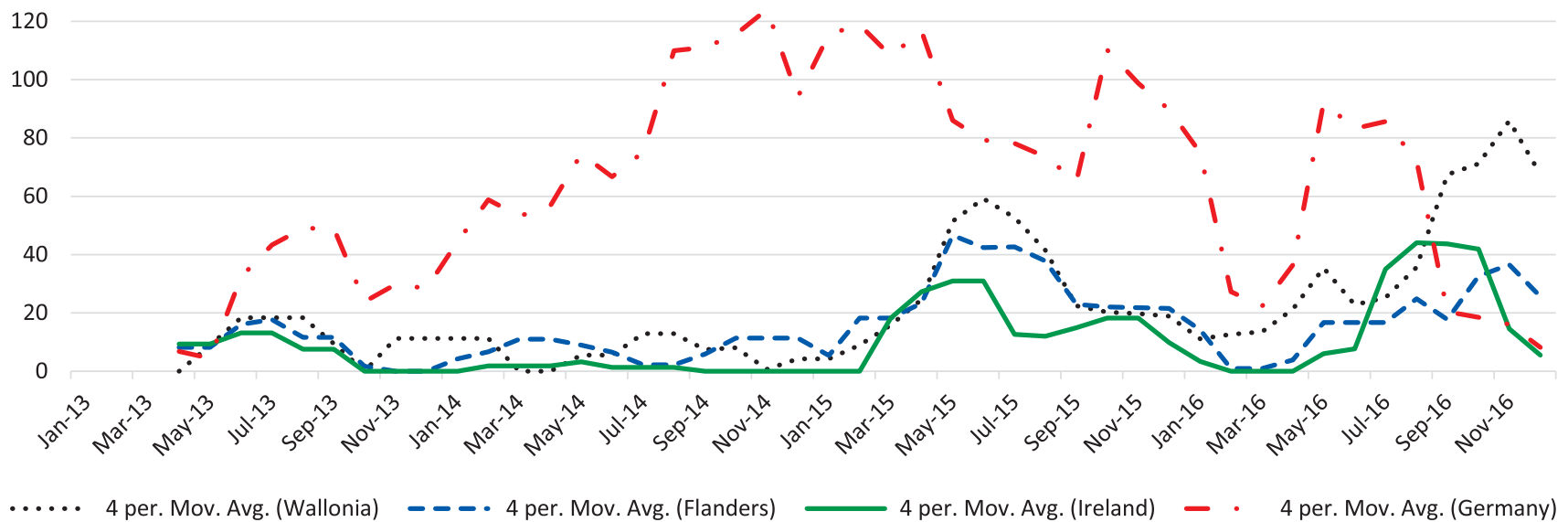

Figure 1. Politicization indices over time for Germany, Ireland, Flanders and Wallonia. Source: Own elaboration (Gheyle, 2019).

\section{Analysis}

\subsection{Transnational and Supranational Connections}

In the EU trade policy domain, the so-called 'Seattle 2 Brussels' (S2B) network is the main transnational advocacy coalition that has been actively following trade issues since the 1999 Seattle demonstrations against the WTO (Interview 1). It is made up of activists who represent different (domestic) organizations, aligned by their values and commitment to challenge the (in their eyes) corporate-driven agenda of the EU. While its membership has fluctuated over the years (mirroring the general attention for trade policy), the core group of members are activist veterans who have been involved in various contentious trade episodes (Interview 2).

Over the years, they have particularly taken up more complex trade topics (which not necessarily drew much public attention) such as trade in services or investment protection (Interview 3). This continuous involvement has therefore not only resulted in long-standing coordination experience, but also in a significant build-up of expertise related to both the (technical) content of agreements, and the way to communicate this to a broader audience. Given the way in which TTIP built upon previous trade and investment agreements, these activists could hence foresee the direction wherein several elements would go (Interview 4). As one interviewee argued: "The moment TTIP took off in 2013, all the material, the discourse, everything on investment and ISDS [InvestorState Dispute Settlement] was ready" (Interview 1).

As the core network working on trade, they took up a coordinating role, and decided early on that this campaign against TTIP should be pan-European from the start (Interview 2). They were, in retrospect, mesomobilization actors at transnational level, responsible for convening meetings, facilitating information exchange, and establishing e-mail lists. While they had no intention to coordinate every message or action, they still "invested a lot of time and capacity in trying to hold [everything] together somehow...to make sure that you're not running in completely different directions" (Interview 4).

Given that its members are national organizations, the S2B-link through domestic groups was acknowledged as an important element in the early mobilization in some EU Member States: "At least in Belgium, the Netherlands, Germany, France, the UK and Spain, it is extremely clear that it were S2B members that kick-started the process and also built alliances that were bigger" (Interview 2). While activists hesitated to assign causality, and argued S2B-members were not solely responsible for the start nor successfulness of domestic politicization, they were nevertheless heavily involved in spearheading the movement domestically.

While S2B is in essence a network of trade experts who are engaged in policy and communication work, a second (but related) transnational alliance formed during the TTIP negotiations. The 'STOP TTIP' Alliance was established somewhere around March 2014, initially in the context of a European Citizens Initiative in order to collect signatures for a petition to stop TTIP. Over time their raison d'être evolved towards becoming the main 'mobilization pillar' of the anti-TTIP movement, responsible for coordinating pan-European events such as the 'European Days of Action against TTIP' (Interview 5). Similar to S2B members who were focal points of domestic campaigns, national STOP TTIP coordinators operated as the main contact points around which national networks were established, in order to work towards demonstrations and actions.

Lastly, besides these trade or TTIP-specific alliances, there were obviously many 'supranational' groups following the negotiations in the EU bubble. The most prominent in this campaign were the European Consumers Organization, the European Trade Union Confederation (the umbrella of trade unions), and a variety of environmental organizations such as Friends of the Earth or Greenpeace. While doing injustice to the intrica- 
cies of alliances and networks at EU level, the key thing to note here is that all these organizations equally have domestic links in different EU Member States.

\subsection{Germany}

Having multiple German links to the S2B-network seems to be one of the main reasons of early German contestation against TTIP. In April 2013 (three months before negotiations started) about 20 NGOs were already meeting to exchange information about the upcoming transatlantic deal (Interviews 4 and 6). The meeting was organized by two S2B-members (CEO and PowerShift) and Campact, a group whose expertise lies in amplifying (online) campaigns. Several other attendees such as ATTAC Germany, GermanWatch or Forum Umwelt \& Entwicklung, were all S2B members, and were hence all very much aware of the (in their view) dangers of the evolving trade agenda.

This group organized several outreach events to raise awareness, and to provide expert training in order to draw more organizations in. Several existing organizational links were activated here, which had evolved naturally, or because of earlier campaigns. Many German environmental and food safety organizations, for example, have allied closely in the past during food safety campaigns (Miltner, Maier, Pfetsch, \& Waldherr, 2013). During these trainings, the German 'mesomobilization' actors taking the lead were CEO, PowerShift and Forum Umwelt \& Entwicklung. They were responsible for coordination, education, and producing the first position papers of the coalition. Testimony of their early work is that on 17 June 2013-the day negotiations were officially announced at a G8 meeting-a paper with the title TTIP nein danke was already made public.

The demands in this paper were incredibly detailed, which is testimony of the professionalization and expertise flowing in the network through different expert groups (working on fracking, pesticides, or the REACH-regulation, for example). This is an element an S2B-interviewee identified as key to the early German mobilization, much less prominent in other countries (interview 2). Moreover, demands were also very diverse: nearly every frame, and every type of concern that was raised during the 3-year campaign was already addressed herein.

In order to get different organizations in line, framing apparently played an important role, as testified by one interviewee: "Groups very much shape the discourse, the frame, but this also shapes the movement in the way that it organizes" (Interview 4). This is reflected, for example, in the name the coalition gave itself: 'TTIP UnfairHandelbar,' which can loosely be translated as "TTIP should not be up for negotiation." The 'unfair' part, however, also makes the name ambiguous enough so that more moderate organizations can claim to campaign for 'reforming' TTIP, while still being included in the wider coalition.
As online and mass media salience grew as a result of the coalitions' early actions, the 'TTIP Unfairhandelbar' coalition grew from 20 to 50 members. Most of these were environmental, alter-globalization, food safety, and development groups, who were closely aligned with the Green and Far-Left political parties, which explains some of the early parliamentary activity in the Bundestag. All in all, German activists acknowledged the vital importance of these coalition formation efforts in the first months. As one interviewee summarized:

For Germany it's actually really clear: It was an early mover advantage...the fact that you had a coalition, that you had a strong narrative with ISDS, the Vattenfall cases, and also organizations like Greenpeace Germany who did very early research on the agenda of the US agribusiness lobby for TTIP. (Interview 4)

Multiple transnational links to S2B (where the trade expertise resided), pre-existing alliances (combining all types of resources), and inclusiveness in framing all played an important role in this early coalition formation.

Still, the biggest and most prominent 'expansion' came when groups with a more 'reformist' stance teamed up. The German trade unions in particular (through their umbrella organization DGB [Deutscher Gewerkschaftsbund]) were widely identified as playing a huge role in further politicizing TTIP (Interviews 3, 4, and 6). The public salience and some skeptical union sections forced DGB to make their concerns public, which they did with their 'red-line approach' by mid-2014 (Interview 7). This reformist stance initially precluded close cooperation with 'TTIP Unfairhandelbar,' as it did not fit with their rejectionist undertone. The solution again lay in framing and coalition formation. The unions and the existing coalition decided to establish a separate, and larger, 'demonstration coalition' under the (loosely translated) banner 'Stop TTIP-For fair trade.' This framing was again inclusive (or ambiguous) enough to house groups aiming to reject or reform TTIP (Interviews 4 and 7).

While the demo coalition proved convenient to bring a heterogeneous alliance of groups together on the streets (such as cultural, religious or small and mediumsized enterprises organizations), the newly made alliances were consequential for others as well. The main German consumer organization (Verbraucherzentrale Bundesverband, VZBV), for example, made its own critical analyses based on its connections with the European Consumers Organization. Still, the red-line position by the unions was very similar to theirs, which led to a joint DGB-VZBV position in July 2014 (Interview 8). The pooled reputation of these groups not only legitimated the concerns about TTIP in the public eye, but it also opened up additional access to more centrist socialdemocratic and Christian-democratic parties, making TTIP a concern for almost the entire political spectrum. 


\subsection{Ireland}

The main Irish coalition against TTIP formed under the banner of the 'TTIP Information Network.' This was initially brought together by activists from ATTAC Ireland and Comhlamh (an umbrella organization for volunteers active in North-South development work). While both these organizations had some in-house expertise, focusing on these two is characteristic for the network as a whole. First of all, this network was quite small (10-15 members), with participants mostly present as volunteers rather than as full-time representatives for their organizations. As one interviewee put it: "It was a very heavy workload amongst quite a small group of civil society organizations. Very intense couple of years for people who did this in their own time" (Interview 9).

Secondly, the two 'founding' groups do not have a long-standing relationship, nor are they embedded in lively networks building on other campaigns. Irish civil society is in general not particularly large, with organizations having to strategically focus on certain topics instead of campaigning on everything (Interviews 9 and 10). This often precludes additional time investments in networks to follow shared topics, especially on topics such as trade which did not attract attention for a long time. Hence, when TTIP took off, there was hardly any organization actively working on EU trade policy (Interview 11). So, while the TTIP Information Network did eventually manage to bring a variety of individuals together, organizations themselves long hesitated to invest much in it.

This volunteer-driven network therefore not only struggled with a lack of time and financial resources, but also a lack of expertise. Training was mostly provided by individuals with some expertise (partly built up through transnational links), but this remained quite limited (Interviews 9 and 11). There were no existing links at the time with S2B, for example, which meant that identification and awareness raising was not timely, nor was there much knowledge in terms of content and framing to draw on. In other words, much of the coalition formation and build-up of expertise still had to take off by the time negotiations were well underway.

Even during coalition formation, members of the network acknowledged several problems. There was a lot of disagreement on the type of actions to be taken, or how to present TTIP to a broader public. An interviewee argued: "It seemed to me that the meetings took place between different groups who each wanted to oppose TTIP on the basis of their own interest and concerns, rather than have a unified strategy" (Interview 12). One idea was to frame TTIP related to agriculture, which in the Irish context could have struck a chord, "but it didn't go that way, people wanted to campaign on their own grounds" (Interview 11). Another activist did not only blame a lack of willingness, but also the complexity of TTIP, citing a multitude of entry points into the debate as a stumbling block (Interview 9). A lack of expertise on how to communicate these trade issues thus again played a role.

These problems of getting an inclusive framing were echoed in the evaluation that there was no central steering group, or at least a full-time coordinator or communications officer (Interview 9). With respect to gaining media coverage, for example, groups argued they knew beforehand this would be difficult in the Irish context, but "to criticize ourselves though, we never had any organized media strategy. It was all ad hoc efforts" (Interview 12). All in all, these volunteers concluded that "it was a small group, it wasn't all that well-organized and it did what it could in quite an ad hoc way" (Interview 12).

Later in the campaign, by 2015, there were additional developments that amplified the message of the TTIP Information Network. For one, the campaign got to some extent linked to broader (and more successful) social movement campaigns against privatizing water distribution (Interview 11). In addition, the Irish trade unions and an organization called 'Uplift' joined the opposition, of which the latter helped grass-roots mobilization through 'TTIP-free zones' or social media campaigns. Also, the Irish section of the pan-European Stop TTIP was set up. All these additional links added certain tactics, mobilization power, or legitimacy that the initial coalition lacked to some extent (Interview 13).

\subsection{Belgium}

Belgian politics is characterized by a divide between the Dutch-speaking (Flanders) and French-speaking (Wallonia) regions, which was no different during the TTIP episode. Coalition building and anti-TTIP campaigns to some extent evolved separately, but many links still exist across the language barrier. The best example hereof is the twin (Flanders-Wallonia) umbrella organization '11.11.11-CNCD,' a North-South development organization that brings together about 60-90 NGOs, (sections of) unions, and smaller associations. They are the only Belgian members of S2B, with interviewees confirming their importance in kick-starting the campaign in both Flanders and Wallonia (Interviews 3 and 14).

In Flanders, 11.11.11 acted as the main mesomobilization actor, trying to bring together different Flemish organizations, providing training, and doing much of the early (inside) lobbying work. It was able to build on an existing 'Decent Work' alliance together with the unions and a handful of global justice organizations. Nonetheless, it took a while (until May 2014) before this coalition came out strongly on TTIP, mainly because of the (Flemish) unions' hesitance to be perceived as anti-trade (Interview 15). They were more in line with the constructive 'red line' position favored by the European Trade Union Confederation. An interviewee from 11.11 .11 acknowledged that they made several compromises and came out much less rejectionist as they wanted to be, in order to get to a joint position (Interview 3). 
In Wallonia, CNCD played a similar role as in Flanders, but here, there were several other (mobilization) networks already active in awareness raising and mobilization, which they were able to build on. First, there was the platform 'No Transat,' originally established by two researcher-activists back in 2009 (who started anticipating what a transatlantic free trade deal would look like). Between 2011-2013, they were vital in raising awareness with other organizations, with several interviewees attributing the early Walloon mobilization to their involvement (Interviews 14 and 16). Secondly, the mobilization of the 'D19-20 Alliance' (originally established by concerned milk producers who saw the need of linking their concerns with other civil society actors) brought a very heterogeneous alliance on the streets, turning its attention to TTIP. Many vocal and more radical sections of Walloon unions were part of both these networks, accounting for a much more militant stance of the Walloon unions. One Walloon activist also recalled that all these coalitions worked together with the idea of a common project: "Everyone had its own institutional affiliation, but nobody tried to make the debate exclusively about him or herself" (Interview 16).

In 2015, a second round of coalition formation took place that was more geared towards cross-regional links. On the one hand there was a joining of forces of the 'expert' pillars that existed in both Flanders and Wallonia, culminating in the ' 4 May Coalition.' This linked the Decent Work coalition together with a list of organizations that had hardly worked on EU trade policy explicitly before (or at least not recently): health insurance funds, consumer groups, and environmental organizations. The coalition boasted that this was the entire Belgian civil society joined together, and interviewees acknowledged that pooling resources was important at that point: Health insurance and consumer groups greatly added to the legitimacy of the 'Stop TTIP' message, while they themselves could more efficiently follow and learn about negotiations (Interviews 17 and 18).

Again, inclusive framing was raised as essential to bring very different groups together. An interviewee from 11.11 .11 argued:

We have stronger stances on trade policy than the consumers, for example, but we don't have problems to ally with them in a coalition where they can recognize themselves in. Eventually that became a broad coalition that also says 'Stop TTIP,' but that does not mean they go as far in their rejection as we do. (Interview 3)

On the other hand, by the end of 2015, a national and much broader 'Stop TTIP-CETA coalition' was established, along the same lines as the 'demonstration coalition' in Germany. This brought the more institutionalized groups together with the (mostly Walloon) mobilization networks of D19-20, and other social movements such as Hart Boven Hard (fighting austerity) and the Climate Coalition. For this, CNCD acted as the mesomobilization actor to coordinate demonstration and actions, building on the loose network that was brought together under the Belgian pillar of the Stop TTIP European Citizens' Initiative (Interview 14). Especially for Flemish organizations this was a welcome step as they could now use the 'tools' and coalitions that had evolved on the Walloon side (Interview 3). Very different groups were aligned here, with one interviewee stating they had many meetings to establish the message: "And the compromise between 'no' and 'suspend' was 'stop,' because stop doesn't mean no" (Interview 14).

In 2016 finally, additional structure was added to this broad coalition, transforming it into the 'Stop TTIP \& CETA Alliance.' It is not entirely clear how the different structures differed from each other (there are many overlaps in membership and actions), but at the very least this was marketed as the first 'national' platform bridging all Flemish and Walloon groups, and giving more structure to the demonstration coalition that was established before. This alliance undertook several smaller actions during summer, leading up to a climax in September 2016, when between 10,000-15,000 people took to the streets of Brussels protesting against both TTIP and CETA.

\section{Discussion and Conclusion}

In this contribution, I have explored domestic coalition formation dynamics in the differentiated politicization of TTIP. By collecting testimonies from German, Irish and Belgian civil society activists, and analyzing campaign material and website information, I was able to identify and further qualify three domestic coalition-facilitating factors, which greatly helped to kick-start the TTIP issue in the domestic public debate, hence signifying its role and importance.

First, I expected a prominent role for mesomobilization actors as crucial organizing and coordinating cogs. The findings confirm the importance of groups taking the lead, especially those with a close interconnectedness to transnational or supranational trade networks. Both in Germany and Belgium, domestic campaigns were kickstarted by mesomobilization actors who were active in, or had access to expertise of trade campaigning through, the S2B-network. In Ireland, the lack of any such connection meant that there was a relatively late awareness of the issue, and a knowledge deficit of how to campaign on such large trade agreements. One idiosyncrasy further qualifying this finding, is the Walloon case of very early awareness raising by one organization (NoTransat), which already alerted other (mobilization) groups before negotiations took off. This emphasizes the expertisedimension in this mesomobilization success, corroborating a finding by Crespy (2016) that politicization "consists to a large extent of the empowerment of contentious actors with expertise, and the use of expertise and communication to translate technical problems into political arguments aimed at mobilizing support" (p. 19). 
Secondly, pre-existing alliances allow for a reactivation of earlier cooperation, while bringing together a diverse set of expertise and mobilization power. This is true in any case for the S2B-network on a transnational level, showcasing the importance of sustaining alliances in between campaigns. In Germany and Belgium as well, civil society organizations are embedded in dense networks, with several existing alliances building on a variety of past campaigns. The variety of groups linked in this way, in combination with early mesomobilization efforts, made an early and thorough condemnation of TTIP possible in Germany and Wallonia. In Flanders, mobilization potential was added especially after linking with Walloon partners, while in Ireland a small and scattered civil society encountered several hurdles associated with coming to terms with a new topic and new alliances, which always remained a volunteer-driven alliance.

Lastly, mesomobilization actors played another crucial role by being flexible and inclusive in framing TTIP, and getting a minimal level of understanding and commitment of all coalition members. This resulted in three significant developments. First of all, in Germany and Wallonia, mobilization was able to take off quickly as many agreed on how to frame TTIP, and what the ultimate goal was. In Flanders, this process took much longer (given the hesitance of trade unions), while in Ireland this was never resolved. Secondly, inclusive framing equally played a role later on, when more groups joined the bandwagon and started focusing on TTIP: Only when agreement on the message and institutional dynamics (see the 'demonstration coalition') was found, did mobilization surge, fueling politicization. Thirdly, flexible issue framing means that groups with substantial expertise and those with mobilization power could be brought together, a useful combination in order to focus on inside and outside lobbying channels simultaneously.

One common thread in these observations is timing. What these existing alliances (domestically, supraor transnationally) and flexible ways of presenting concerns have especially facilitated is an early mover advantage. Besides the ferocity with which claims can be put forward, or the overall legitimacy a coalition has by being diverse, these timing-related elements of coalition formation especially contributed to a rapid kick-off of the debate, putting the burden of counter-framing the TTIP topic on the actor that comes in second, and who needs to convince an increasingly skeptical audience of the benefits of TTIP.

Such an observation is also important in order to identify the next steps of uncovering and/or explaining politicization processes. By no means is the conclusion here that coalition formation dynamics is the only important factor to consider in what is, by definition, a complex phenomenon that can materialize through different pathways (think, for example, of media culture, political party constellations, or public sentiments towards negotiating partner, as other possible factors). Yet it suggests that in a multi-causal explanation of politicization, do- mestic coalition patterns will probably play a significant role, which we can either use as part of (time-sensitive) causal mechanisms uncovered through process-tracing, or as a condition in a qualitative comparative analysis.

\section{Acknowledgments}

The author wishes to thank the Academic Editors of this thematic issue, the three anonymous reviewers, and Ferdi De Ville, for most helpful comments on earlier drafts of this article.

\section{Conflict of Interests}

The author declares no conflict of interests.

\section{Supplementary Material}

Supplementary material for this article is available online in the format provided by the authors (unedited).

\section{References}

Baglioni, S., \& Hurrelmann, A. (2016). The Eurozone crisis and citizen engagement in EU affairs. West European Politics, 39(1), 104-124.

Baumgartner, F., \& Mahoney, C. (2008). The two faces of framing: Individual-level framing and collective issuedefinition in the EU. European Union Politics, 9(3), 435-449.

Benford, R. D., \& Snow, D. A. (2000). Framing processes and social movements: An overview and assessment. Annual Review of Sociology, 26(1), 611-639.

Bollen, Y., De Ville, F., \& Gheyle, N. (2020). From nada to Namur: Sub-federal parliaments' involvement in European Union trade politics, and the case of Belgium. In J. Broschek \& P. Goff (Eds.), The multilevel politics of trade (pp. 256-278). Toronto: University of Toronto Press.

Buonanno, L. A. (2017). The new trade deals and the mobilisation of civil society organizations: Comparing EU and US responses. Journal of European Integration, 39(7), 795-809.

Chan, A. T., \& Crawford, B. K. (2017). The puzzle of public opposition to TTIP in Germany. Business and Politics, 19(4), 683-708.

Crespy, A. (2014). A dialogue of the deaf? Conflicting discourses over the EU and services liberalisation in the WTO. The British Journal of Politics and International Relations, 16(1), 168-187.

Crespy, A. (2016). Welfare markets in Europe: The democratic challenge of European integration. London: Palgrave Macmillan.

Crespy, A., \& Parks, L. (2017). The connection between parliamentary and extra-parliamentary opposition in the EU: From ACTA to the financial crisis. Journal of European Integration, 39(4), 453-467.

De Bièvre, D., \& Poletti, A. (2017). Why the Transatlantic 
Trade and Investment Partnership is not (so) new, and why it is also not (so) bad. Journal of European Public Policy, 24(10), 1506-1521.

De Ville, F., \& Siles-Brügge, G. (2015). TTIP: The truth about the Transatlantic Trade and Investment Partnership. Cambridge: Polity Press.

De Ville, F., \& Siles-Brügge, G. (2017). Why TTIP is a gamechanger and its critics have a point. Journal of European Public Policy, 24(10), 1491-1505.

de Wilde, P. (2011). No polity for old politics? A framework for analyzing the politicization of European integration. Journal of European Integration, 33(5), 559-575.

de Wilde, P., Leupold, A., \& Schmidtke, H. (2016). Introduction: The differentiated politicisation of European governance. West European Politics, 39(1), 3-22.

de Wilde, P., \& Zürn, M. (2012). Can the politicization of European integration be reversed? Journal of Common Market Studies, 50(1), 137-153.

Duina, F. (2019). Why the excitement? Values, identities, and the politicization of EU trade policy with North America. Journal of European Public Policy, 26(12), 1866-1882.

Edwards, B., \& McCarthy, J. D. (2007). Resources and social movement mobilization. In D. A. Snow, S. A. Soule, \& H. Kriesi (Eds.), The Blackwell companion to social movements (pp. 116-152). Oxford: Blackwell Publishing Ltd.

Eliasson, L. J., \& Garcia-Duran, P. (2018). TTIP negotiations: Interest groups, anti-TTIP civil society campaigns and public opinion. Journal of Transatlantic Studies, 16(2), 101-116.

Friedrichs, J., \& Kratochwil, F. (2009). On acting and knowing: How pragmatism can advance international relations research and methodology. International Organization, 63(4), 701-731.

Gerhards, J., \& Rucht, D. (1992). Mesomobilization: Organizing and framing in two protest campaigns in West Germany. American Journal of Sociology, 98(3), 555-596.

Gheyle, N. (2019). Trade policy with the lights on: The origins, dynamics, and consequences of the politicization of TTIP (Doctoral dissertation). Ghent University, Ghent, Belgium.

Jedinger, A., \& Schoen, A. (2018). Anti-Americanism and public attitudes toward transatlantic trade. German Politics, 27(3), 317-338.

Junk, W. M. (2019). Co-operation as currency: How active coalitions affect lobbying success. Journal of European Public Policy. https://doi.org/10.1080/ 13501763.2019.1631377

Junk, W. M., \& Rasmussen, A. (2019). Framing by the flock: Collective issue definition and advocacy success. Comparative Political Studies, 52(4), 483-513.

Keck, M. E., \& Sikkink, K. (1999). Transnational advocacy networks in international and regional politics. Inter- national Social Science Journal, 51(159), 89-101.

Laursen, F., \& Roederer-Rynning, C. (2017). Introduction: The new EU FTAs as contentious market regulation. Journal of European Integration, 39(7), 763-779.

Levi, M., \& Murphy, G. H. (2006). Coalitions of contention: The case of the WTO protests in Seattle. Political Studies, 54(4), 651-670.

McCarthy, J. D., \& Zald, M. N. (1977). Resource mobilization and social movements: A partial theory. American Journal of Sociology, 82(6), 1212-1241.

Meunier, S., \& Czesana, R. (2019). From back rooms to the street? A research agenda for explaining variation in the public salience of trade policy-making in Europe. Journal of European Public Policy, 26(12), 1847-1865.

Miltner, P., Maier, D., Pfetsch, B., \& Waldherr, A. (2013). Online networks of civil society actors as an indicator for politicization? A hyperlink analysis of the food safety issue in Germany. Catalan Journal of Communication \& Cultural Studies, 5(2), 201-220.

Palonen, K., Wiesner, C., Selk, V., Kauppi, N., Trenz, H.-J., Dupuy, C., . . . Liste, P. (2019). Rethinking politicisation. Contemporary Political Theory, 18(2), 248-281.

Rohlfing, I. (2012). Case studies and causal inference: An integrative framework. London: Palgrave Macmillan.

Schmidt, V. A. (2019). Politicization in the EU: Between national politics and EU political dynamics. Journal of European Public Policy, 26(7), 1-19.

Staggenborg, S. (2002). The "meso" in social movement research. In D. Meyer, N. Whittier, \& B. Robnett (Eds.), Social movements: Identity, culture, and the state. Oxford: Oxford University Press.

Statham, P., \& Trenz, H.-J. (2013). How European Union politicization can emerge through contestation: The constitution case. Journal of Common Market Studies, 51(5), 965-980.

Von Bülow, M. (2010). Building transnational networks: Civil society and the politics of trade in the Americas. New York, NY: Cambridge University Press.

Walter, A. (2001). NGOs, business, and international investment: The multilateral agreement on investment, Seattle, and beyond. Global Governance, 7(1), 51-74.

Young, A. R. (2016). Not your parents' trade politics: The Transatlantic Trade and Investment Partnership negotiations. Review of International Political Economy, 23(3), 345-378.

Young, A. R. (2017). The new politics of trade: Lessons from TTIP. Newcastle-upon-Tyne: Agenda Publishing.

Zürn, M. (2016). Opening up Europe: Next steps in politicisation research. West European Politics, 39(1), 164-182.

Zürn, M. (2018). A theory of global governance: Authority, legitimacy, and contestation. Oxford: Oxford University Press. 


\section{About the Author}

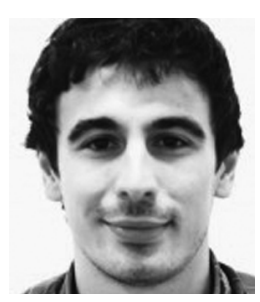

Niels Gheyle is Postdoctoral Researcher at the Center for EU Studies, Ghent University, where he obtained his doctoral degree with a thesis on The Origins, Dynamics, and Consequences of the Politicization of TTIP. His work focuses on the (de)politicization of global governance, the EU, and EU trade policy in particular. 